Bangladesh Med Res Counc Bull 2010; 36: 1-3

DOI: $10.3329 /$ bmrcb.v36il.4479

\title{
Swelling of vallate papillae of the tongue following arsenic exposure
}

\author{
A.F.M. Sarwar ${ }^{1}$, Sk. Akhtar Ahmad ${ }^{2}$, Manzurul Haque Khan ${ }^{2}$, M.H. Salim Ullah Sayed ${ }^{2}$ \\ and Md. Humayun Kabir ${ }^{3}$ \\ ${ }^{1}$ Department of Children, Preventive and Community Dentistry, Dhaka Dental College, Mirpur 14, Dhaka \\ 1206; ${ }^{2}$ Department of Occupational and Environmental Health, National Institute of Preventive \& Social \\ Medicine (NIPSOM), Mohakhali, Dhaka 1212; ${ }^{3}$ Department of Dentistry, Shaheed Suhrawardy Medical \\ College, Sher-E- Bangla Nagar, Dhaka 1207, Bangladesh.e-mail: drsarwarbd@gmail.com
}

\begin{abstract}
This cross-sectional study was carried out in some selected arsenic contaminated rural areas of Bangladesh to determine any clinical changes in oral cavity, among the arsenic exposed population through drinking water. Total 600 respondents (200 arsenicosis patients, 200 non-patients but having the history of taking arsenic contaminated water and another 200 arsenic non-exposed). $75.5 \%$ of arsenicosis patients had swelled vallate papillae whereas only $44.5 \%$ and $8.5 \%$ in case of arsenic exposure and non-exposure subjects respectively. The differences were found statistically significant $(p<0.001)$. This study suggests that there is a tendency of developing swelled vallate papillae among the arsenic exposed population.
\end{abstract}

\section{Introduction}

Millions of people in Bangladesh are consuming arsenic through drinking water and food ${ }^{1}$. This leads to pigmentary changes (melanosis), keratosis usually melanosis are found on trunk and gradually covers whole body ${ }^{2}$. Some sign and symptoms are also seen in other tissues of the body like tongue, gingival and buccal mucosa ${ }^{3}$. Arsenic was once used topically as pulp devitalize for endodontic treatment, arsenic is toxic to vital pulp due to prolonged leakage of arsenic trioxide can cause severe damage to periodontal tissues and also can widespread necrosis of gingiva and bone, which can lead to osteomyelitis of the jaws ${ }^{4}$.

So far knowledge goes any significant study on oral health in relation to arsenic has not been done. So this study will help in endeavors towards reducing the effects caused by arsenicosis in the oral cavity.

\section{Methods and Materials}

It was a cross-sectional study with comparison groups to determine any clinical changes in oral cavity among those people who were consuming high concentration of arsenic in water. This study was conducted in some villages of highly contaminated tubewell with arsenic in the districts of Jessore, Kishoregonj, Chapai Nawabgonj and Narayangonj. Accordingly arsenic nonexposed villages were selected from Kishoregonj, Gazipur and Chapai Nawabgonj districts. A total of 600 respondents who were selected from the above mentioned villages (200 hundred respondents who were exposed to arsenic contaminated water $(\mathrm{p}>0.05 \mathrm{mg} / \mathrm{L})$ having the sign of melanosis and/or keratosis, 200 those who were exposed to arsenic contaminated water ( $p>0.05$ $\mathrm{mg} / \mathrm{L}$ ) but without any clinical menifastations and the rest 200 who were not exposed to arsenic contaminated water). Water samples were analyzed by the help of NIPSOM field kit ${ }^{5}$. In calculating the sample size, as per WHO sample size determination criteria by the following formula for two-sample situation was: -

$\mathrm{n}=\mathrm{Z}^{2}(1-\alpha)\left\{\mathrm{P}_{1}\left(1-\mathrm{P}_{1}\right)+\mathrm{P}_{2}\left(1-\mathrm{P}_{2}\right)\right\} / \mathrm{d}^{2}$

Where $Z=Z$ score $=1.96$; $\mathrm{d}=$ acceptable level of error $=10 ; \mathrm{P}_{1} \& \mathrm{P}_{2}=$ The anticipated population of adverse effect of oral health status in arsenic exposed and non-exposed population were set at $50 \%$ i.e. 0.5 because of available literature does not provide any estimation of the anticipated prevalence rate. This 0 . 5 for $\mathrm{P}_{1} \& \mathrm{P}_{2}$ provide the largest sample size. However it had been taken comparatively large value 
for error $(\mathrm{d})=0.10$ to keep the sample to a manageable size $=192.08$ or 193 by using above mentioned formula. In this study the inflation of the sample size by an arbitrary $193^{6}$ figure of 7 as a check against possible drop out due to inconsistency or incomplete questionnaire and refusal of participation of respondents. Thus the final sample size was $(193+7)=200$ in each group so total sample size was $200 \times 3=600$. Enlisted individuals fulfilling the criteria for inclusion in the study through house-tohouse visit and selected the required number of respondents by a pre-tested combined structured questionnaire and a checklist to interview. At the beginning of interview, the purpose of the study was explained to each respondent, and his or her verbal consent to participate in the study was obtained.

The respondents were interviewed and examined one by one in the medical camp by sitting position on an examination chair. Oral cavity was examined by the help of disposable dental mirror, probe, tongue depressor and a pencil torch to inspect the state of the oral cavity as well as the condition of the tongue.

\section{Results}

Table I shows that $75.5 \%$ swelled vallate papillae were found those who were suffering from arsenicosis, $44.5 \%$ had the same among those who were exposed to arsenic through drinking water without having the sign symptoms of arsenicosis but only $8.5 \%$ had the same those who were consuming arsenic free water or within the permissible limit and was found statistically significant difference among the study groups.

Table I: Distribution of swelling of vallate papillae among the arsenic exposed and non-exposed population

\begin{tabular}{|c|c|c|}
\hline $\begin{array}{l}\text { Categories according to arsenic } \\
\text { exposure }\end{array}$ & $\begin{array}{l}\text { Swelled vallate } \\
\text { papillae }\end{array}$ & $\begin{array}{c}\text { Test of } \\
\text { significance }\end{array}$ \\
\hline Arsenicosis patients $(\mathrm{n}=200)$ & 151 & $\chi_{(2)}^{2}=$ \\
\hline $\begin{array}{l}\text { Arsenic exposed non-patient } \\
(\mathrm{n}=200)\end{array}$ & 89 & $\begin{array}{l}183.67 \\
\mathrm{p}=.000\end{array}$ \\
\hline Arsenic non-exposed $(\mathrm{n}=200)$ & 17 & $\mathrm{p}<0.001$ \\
\hline
\end{tabular}

Table II shows that the arsenicosis patients had swelled vallate papillae was $66.7 \%, 70.5 \%, 81.9 \%$ and $90.9 \%$ among the age group of up to 20 years, 21-40 years, and 41-60 years and above 60 years respectively. The same manifestation was also observed $36.7 \%, 36.5 \%, 65.3 \%$ and 66.7 accordingly those who were exposed to arsenic through drinking water without having the sign-symptoms of arsenicosis. Whereas in the arsenic non-exposed had the same $2.9 \%, 7.3 \%, 10.4 \%$ and $42.9 \%$ at the same chronological age groups distribution. This table also showed that the swelled vallate papillae were raised according to the rising of the ages so age is one of the factors to develop such condition. But it is also clear that the swelled vallate papilaae were higher in those who were exposed to arsenic and was found to be statistically significant $(\mathrm{p}<0.001)$.

Table II: Distribution of swelling of vallate papillae among the arsenic exposed and non-exposed population according to age

\begin{tabular}{lcccc}
\hline Age (years) & $\begin{array}{c}\text { Arsenicosis } \\
\text { patient }\end{array}$ & $\begin{array}{c}\text { Arsenic } \\
\text { exposed } \\
\text { non patient }\end{array}$ & $\begin{array}{c}\text { Arsenic } \\
\text { non- } \\
\text { exposed }\end{array}$ & $\begin{array}{c}\text { Test of } \\
\text { significance }\end{array}$ \\
\hline$<20$ & 8 & 11 & 1 & $\begin{array}{c}\chi^{2}=21.84 \\
\mathrm{df} 2\end{array}$ \\
& $(12)$ & $(30)$ & $(35)$ & $\mathrm{p}<0.001$ \\
$21-40$ & 74 & 42 & 8 & $\begin{array}{c}\chi^{2}=91.97 \\
\mathrm{df} 2\end{array}$ \\
& $(105)$ & $(115)$ & $(110)$ & $\begin{array}{c}\mathrm{p}<0.001 \\
\chi^{2}=62.08 \\
\mathrm{~d}-60\end{array}$ \\
& 59 & 32 & 5 & $\begin{array}{c}\mathrm{df} 2 \\
\mathrm{p}<0.001\end{array}$ \\
$>60$ & $(72)$ & $(49)$ & $(48)$ & $\begin{array}{c}\chi^{2}=4.89 \\
\mathrm{df} 2 \\
\mathrm{p}>0.05\end{array}$ \\
\hline Parenthesis shows the total number of respondents in respective age group
\end{tabular}

Table III shows that the people who were consumed arsenic contaminated water 05 years or less had the swelled vallate papillae $47.8 \%$ and $52.2 \%$ among the arsenicosis patients and arsenic exposed non patient respectively. In case of the people those who were consumed arsenic contained water above 5 years had the same $64.5 \%$ and $35.5 \%$ accordingly and was found statistically significant differences $(\mathrm{p}<0.01)$.

Table III: Distribution of swelling of vallate papillae among the arsenicosis patient and exposed non patient by the duration of arsenic consumption in years

\begin{tabular}{|c|c|c|c|}
\hline $\begin{array}{l}\text { Duration of arsenic } \\
\text { exposure (years) }\end{array}$ & $\begin{array}{c}\text { Arsenicosis } \\
\text { patient }\end{array}$ & $\begin{array}{c}\text { Arsenic } \\
\text { exposed } \\
\text { non patient }\end{array}$ & $\begin{array}{c}\text { Test of } \\
\text { significance }\end{array}$ \\
\hline $\begin{array}{l}5 \text { years or below } \\
(23)\end{array}$ & 11 & 12 & $\begin{array}{c}\chi^{2}=2.62 \\
\text { df } 1 \\
p>0.05\end{array}$ \\
\hline $\begin{array}{l}\text { Above } 5 \text { years } \\
(217)\end{array}$ & 140 & 77 & $\begin{array}{c}\chi^{2}=37.68 \\
\text { df } 1 \\
p<0.001\end{array}$ \\
\hline
\end{tabular}

\section{Discussion}

In arsenic exposed population these appears to be some oral differences especially swelling of the vallate papillae of the tongue, usually the vallate papillae which are 8-12 in number and 1-3 $\mathrm{mm}$ in diameter situated in a row parallel and close to the sulcus terminalis with a flattened circular depression ${ }^{7}$. A case control study from Ron Philbun districts of Nakorn Province in Thailand showed that 
the student who had lived in the arsenic endemic area had higher prevalence of enamel hypoplasia (destruction of enamel), lower caries experience and higher percentage of children who were free from periodontal disease than those of the control group ${ }^{8}$ but the researcher did not take the tongue under consideration. The cause of swelled vallate papillae of tongue are unknown whether arsenic is in same way related to the cause of enamel hypoplasia ${ }^{9}$. But in this study there were a significantly increased prevalence of swelled vallate papillae was found among the subjects with exposed arsenic above the permissible limit compared with subjects who did not exposed to arsenic through drinking water. A significant trend between the age and the prevalence of swelled vallate papillae with arsenic exposure strengthens the possibility of a causal association ${ }^{10}$ this study also showed significant differences in regards to the duration of arsenic exposure to the vallate papillae, a similar phenomenon was found in regards to skin lesion and glucosuria by the duration of arsenic exposure ${ }^{11}$. So the ultimate goal of this study can be a tool for early diagnosis of the arsenicosis. It was felt that further study may be conducted particularly on swelled vallate papillae and attributing to consistent sign for arsenicosis.

In conclusion, this study suggests that there is the tendency of developing swelled vallate papillaeamong the arsenic exposed population.

\section{References}

1. Rmalli SWA, Haris PI, Harrington CF, Ayub M. A survey of arsenic in foodstuffs on sale in the United Kingdom and imported from Bangladesh. Sci Total Environ. 2005; 337: 23-30.
2. Lindberg AL, Rahman M, Persson LÅ, Vahter M. The risk of arsenic induced skin lesions in Bangladeshi men and women is affected by arsenic metabolism and the age at first exposure. Toxicol Appl Pharmacol. 2008; 230: 916.

3. Ahmad SA. Water contamination and health hazard, Udayan Press, Rajshahi. 1st ed. 2000, p 23.

4. Wang X, Zhang J, Liu M, Wei FC. Aseptic necrosis of the maxilla after devitalisation of the teeth with arsenic trioxide Brit J Oral Maxillofacial Surg. 2008; 46: 79-82.

5. Maidul AZM. Chronic arsenic toxicity \& skin problem in Bangladesh. Bangladesh J Dermatol Venerol Leprol. 1997; 14: 1-2.

6. Ahmad SA, Sayed MHSU, Barua S, Khan MH, Faruquee MH, Jalil A, Hadi SA, Talukder HK. Arsenic in drinking water and pregnancy outcomes. Environ Health Persp. 2001; 109: 629-31.

7. Ghom A, Mhaske S. Textbook of pathology. $1^{\text {st }}$ ed. New Delhi, Jaypee Brothers Medical Publisher Ltd. 2009, pp 550-50.

8. Ahmad SA, MHSU Sayed, Hadi SA, Khan AW. Modified arsenic field kit: A cheap and easy device for detection of arsenic in water. JOPSOM, 1997; 16: 143150 .

9. Ahmad SA, Sayed MHSU, Faruquee MH, Khan MH, Jalil MA, Ahmed R, Razzak MA, Moyeen US. Arsenicosis: Sex differentials. JOPSOM 1999; 18: 35-40.

10. Rahman M, Tondel M, Ahmad SA, Axelson O. Diabetes mellitus associated with arsenic exposure in Bangladesh. Amj Epidemiol, 1998; 148: 198-03.

11. Rahman M, Tondel M, Axelson O. Relations between exposure to arsenic, skin lessions and glucosuria. Occup Environ Med. 1999; 56: 277-81. 